\title{
Entre afetos e excessos - respostas de engajamento sensório-sentimental no documentário brasileiro contemporâneo'
}

\author{
Mariana Baltar ${ }^{2}$
}

I Uma primeira versão desse artigo foi apresentada no XXXI International Congress da Latin American Studies Association (LASA), realizado em Washington, nos Estados Unidos, entre os dias 29 de maio/Ol de junho de 2013. O paper compôs a mesa intitulada "Ficções do real no cinema brasileiro contemporâneo", coordenada pela Profa. Dra. Marta Peixoto (New York University) e faz parte da pesquisa Politicas do excesso e narrativas do corpo - pornografia, horror e melodrama como inserts e atrações, desenvolvida no âmbito do grupo de pesquisa Nex - Núcleo de Estudos do Excesso nas Narrativas Audiovisuais (http://www.nexuff.blogspot.com/).

2 Professora da graduação em Estudos de Mídia/UFF e do PPCCOM da UFF, e editora da Contracampo (Revista da Pós-graduação da UFF). Publicou diversos artigos em revistas acadêmicas entre eles "Evidência invisível - Blow Job, vanguarda, documentário e pornografia", na Revista Famecos (2011), e o capítulo "Weeping Reality: Melodramatic Imagination in Contemporary Brazilian Documentary", no livro Latin american melodrama. Passion, pathos, and entertainment (2009). E-mail: marianabaltar@gmail.com 


\section{Resumo}

Este artigo procura pensar sobre modos de articulação do engajamento sensóriosentimental do espectador mobilizados pela narrativa para dar conta de articulações das histórias íntimas e cotidianas nas quais parece se centrar uma tendência importante do documentário brasileiro contemporâneo. Argumentamos, com base na análise comparativa entre os filmes A Falta que me faz (Marília Rocha, 2009) e Elena (Petra Costa, 2012), que ambos os filmes transitam de formas distintas entre os modos de afeto e de excesso como resposta ao paradigma das sensações e da moral da cultura somática que parece marcar a contemporaneidade.

\section{Palavras-chave}

Afeto, Excessos, Documentário brasileiro.

\section{Abstract}

This article addresses the ways in which a sensorial and sentimental engagement can be constructed throughout the narrative in order to convey private, intimate and ordinary stories that seems to be a major tendency among Brazilian contemporary documentaries. Based on the comparative analyses of $A$ falta que me faz (Marília Rocha, 2009) and Elena (Petra Costa, 2012), I would like to argue that both films makes distinguish use of affects and excess and that such aesthetical elements must be understood as sensorial response to the paradigm of the senses and the morality of the somatic culture that seems to characterizes contemporary age

\section{Keywords}

Affect, excess, Brazilian Documentary. 


\section{Introdução}

"Elena, sonhei com você essa noite..." é a primeira fala do filme dirigido por Petra Costa. Pontos de luz na noite, close no reflexo do rosto feminino emoldurado na janela do carro que vaga pela cidade nos fazem adentrar na lembrança dolorosa de uma perda narrada em primeira pessoa ao longo dos 120 minutos do filme. A Falta que me faz também se inicia em um primeiro plano, mas dessa vez não no rosto feminino, mas no colo. Uma série de fotos e a voz que canta "eu amei um alguém, que me amou pra valer...".

Ambos os documentários, dirigidos por mulheres, entram de modos particulares no universo feminino: de um lado, duas mulheres unidas por um evento traumático (o suicídio) que encontram no processo do filme em primeira pessoa certo tipo de fechamento; de outro, uma diretora tenta expressar seu encontro com o universo de outras mulheres ao mesmo tempo próximas e distantes a partir de miradas ao cotidiano de um grupo de amigas na serra mineira. Em ambos os filmes, há um convite endereçado ao nosso olhar sensível e ao nosso sentimento, convite feito a nossa pele para fluir no que em um filme é uma clara narrativa de excesso e em outro, são inserts afetivos em meio à convivência singular que não se pretende totalizante ou estritamente representacional.

Meu argumento é que os filmes tratados aqui expõem duas vertentes (entre outras em ação) de respostas sensíveis à centralidade do cotidiano e do indivíduo como alvo do olhar no contemporâneo como agenciamento de "verdades" e "promessas" de real. Assim, de um lado teríamos a adesão à cultura do excesso através do diálogo com a imaginação melodramática (conforme analiso o Elena) e de outro ( $A$ falta que me faz) uma recusa da representação em favor da intensificação dos afetos-performativos em instantes e fragmentos (por isso o uso aqui do termo inserts) que remolduram o restante do filme.

Minha proposta nesse artigo é articular o afeto e o excesso como estratégias de engajamento sensorial e sentimental no documentário brasileiro 
contemporâneo, respondendo a uma tendência já amplamente mapeada por diversos autores (tais como Consuelo Lins e Claudia Mesquita (2010), Mariana Baltar (2010) entre outros) que de certo modo parecem recusar a tradição representativa em favor de uma "ênfase na dimensão temporal da experiência de pessoas e localidades" (Mesquita, 2008, p. 221) que se manifesta, sobretudo, na valorização do dispositivo como estratégia de "maquinação" (o termo é de Consuelo Lins) da relação entre filme - mundo - espectadores.

Entendo a mobilização do afeto e a ideia de excesso (como inserts reiterativos e saturados de simbolizações no nível da imagem e/ou do som) como estratégias e elementos estéticos distintos, mas passíveis de interconexões que se endereçam ao sensório e ao sentimento dos espectadores, forjando assim uma espécie de pacto entre filme e mundo. Pacto de certo tipo de engajamento que é cada vez mais desejado pelo espectador que habita o contemporâneo marcado pela centralidade das sensações e do corpo em sua moral do espetáculo, conforme teorizam Christopher Türcke (2010) e Jurandir Freire Costa (2004).

Nesse sentido, o afeto e o excesso são pensados a partir do seu potencial de mobilização da dimensão corporal/sensorial do espectador em documentários que desestabilizam o horizonte de expectativas tradicionalmente associado ao gênero, como o fazem A Falta que me faz (Marília Rocha, 2009) e Elena (Petra Costa, 2012), pois ambos, de maneiras bem distintas, de algum modo se articulam a partir do pathos na expressão da intimidade e do cotidiano como esferas privilegiadas de acesso ao real. No filme de Marília Rocha, o pathos se apresenta como afetos em fragmentos do cotidiano de mulheres em Curralinho, interior de Minas Gerais; no de Petra Costa, o excesso nos liga à narração em primeira pessoa e à expressão fílmica de um relato exacerbadamente pessoal.

Se de um lado, o excesso e o afeto podem ser entendidos como estratégias estéticas, de outro, enquanto tal, eles respondem a uma sensibilidade e imaginário geral que atravessa o contexto atual. Deste modo, podemos falar de uma cultura do excesso que perpassa a subjetividade contemporânea e a partir da qual as narrativas, em especial as audiovisuais, fazem sentido. Com isso, não quero argumentar por uma totalização do excesso enquanto elemento estético constante nas obras, mas perceber sua centralidade em face da cultura 
ano 2 número 4

Dossiê

midiática e de um contexto histórico vinculado à lógica e moral do espetáculo. Por conta dessa centralidade, podemos pensar movimentos entre a adesão (mais frequentes sobretudo se tomarmos em consideração toda a tradição de cinema e audiovisual mais ligado ao sistema de gêneros narrativos) e a crítica (seja esta pelo diálogo mais tensionado ou pelo contraponto).

Sendo assim, é importante entender tanto o excesso quanto o afeto como uma resposta sensível a um cenário que demanda mobilizações a partir do engajamento afetivo do corpo, cenário coerente ao contexto do que Jurandir Freire Costa (2004) denominou como cultura somática e do que Christopher Tücker (2010) identificou como uma mudança de paradigma no contemporâneo em direção a um paradigma das sensações. Ambos os conceitos se ancoram na importância da visibilidade/visualidade desde o projeto de modernidade que se adensa no contexto da sociedade pósdisciplinar atravessada pela sociedade do espetáculo.

Em Notas sobre a cultura somática, Jurandir Freire Costa (2004) empreende um mapeamento do lugar do corpo físico no contemporâneo e identifica o que define como a cristalização da moral contemporânea sustentada no corpo, no sensório e no espetáculo. Nesse sentido, segundo o autor, tal moral advinda do que chama de cultura somática, adquire duas faces que ele vai denominar de "moral do espetáculo" e "moral do governo autônomo do corpo" 3 . O que

3. Jurandir Freire Costa identifica duas faces da moral da cultura somática, pois pretende complexificar a percepção de que tal moral seria apenas uma valorização nefasta da lógica do espetáculo tal como diagnosticada por Guy Debord. Tentando não cair numa dicotomia simplista, o autor identifica características que seriam propriamente do que chama "Moral do espetáculo" (supervalorização do hedonismo como finalidade da vida, busca por um "corpo espetacular", entre outras) e outras que dariam conta de uma ideia de autonomia e governo de si, denominada por ele como "Moral do governo autônomo do corpo". Esta outra dimensão da moral vigente responde por uma preocupação ética consigo e com o bem estar do corpo, por uma antinomia do prazer sensorial que compele a resistir ao dever de gozar sensorialmente pela mídia, por uma gama de identidades pessoais disponíveis e por subjetividades antes vistas como deficitárias sendo redefinidas existências singulares indicando assim uma ética somática das diferenças: "A recuperação da dignidade ética pela revalorização das singularidades, tende a se firmar como uma aquisição cultural, a conquista de um lugar de apresentação, atuação e visibilidade" (FREIRE COSTA, Jurandir, 2004, p. 240). Não vou detalhar os argumentos do autor, em sua ampla maioria argumentos de inspiração foucaultiana, mas apontar que, nesse diagnóstico, o corpo e seu aparato sensorial e sentimental são mais que veículos de um jogo racional de constituição de subjetividades e experiências, mas a arena e o dispositivo dessas construções de subjetividades e modos de vida. 
caracteriza a cultura somática e sua moral vigente é uma intensa alteração na percepção cultural do corpo em direção a uma revalorização deste na construção (e disputas) das subjetividades e na dimensão da experiência cotidiana. Assim, o corpo e o sensível são mais que dimensão físico-científica, mas uma arena de disputas político-estéticas que se travam através do corpo e pelo corpo. Nessas disputas, a imagem do corpo em ação como esfera de concretude da corporeidade tem papel privilegiado.

Trago essa discussão pois é a partir desse cenário que se entende a tendência contemporânea de narrativas cinematográficas e audiovisuais cada vez mais intensificadas no seu desejo de "falar" e mobilizar o corpo dos espectadores.

O que Freire Costa nomeia de "cultura somática”, o alemão Christopher Tücker identifica como uma mudança de paradigma no entendimento do mundo. Para ele, estamos na era de um paradigma das sensações que faz com que perceber(-se) e experimentar-se a si mesmo e à realidade cotidiana do mundo é cada vez mais atravessado por um entendimento sensorial. Tal paradigma é ao mesmo tempo efeito e instrumento de uma mudança no aparato sensorial dos sujeitos contemporâneos que, segundo o autor, encontra-se ultrassaturado e desejante de constantes estímulos e choques, o que explicaria a crescente busca sensacional e a valorização do sensório como esfera de saber e de disputas culturais. Tal diagnóstico feito por Tücker corrobora os argumentos sobre a centralidade do corpo na contemporaneidade.

Segundo o autor alemão, a mudança de paradig ma não se deu necessariamente por ruptura com certos preceitos da alta modernidade, mas por aceleração e intensificação. Entre os fatores elencados estão reflexões que apontam para um contexto pós-disciplinar que responde ao desenvolvimento do capitalismo tardio ocidental e à cristalização da uma lógica geral de desregulamentação.

Diante do paradigma das sensações, percebe-se a hegemonia de um regime estético de intensificação do sensacionalismo e da lógica espetacular, bem como o que o autor chama de "compulsão generalizada à emissão", ou seja, o desejo de dar-se a ver/ser percebido como garantia e forma de existência. Nesse contexto, a percepção, reino do sensório, se confunde com imagem, a imagem com presença corpórea e esta é cada vez mais atravessada por um 
ano 2 número 4

Dossiê entendimento de que presença corpórea se confunde com presença midiática. Produzir imagens de si, performances de si para consumo do olhar público, em um jogo de visualidades e visibilidades que encontra na articulação narrativa através do excesso sua expressão mais comum.

Mas é preciso também entender que esse cenário produz suas linhas de fuga e desejos de resistência e que estas podem vir numa adesão tensionada à cultura do excesso e é nessa tensão dialógica que o afeto (e uma apropriação crítica e pontual do excesso) ganha corpo.

Esse contexto contemporâneo impacta sobremaneira o campo do cinema e do audiovisual e em alguma medida suas narrativas buscam traduzir no corpo toda a preocupação com a intimidade, o indivíduo e o cotidiano como lócus de expressão cultural e subjetiva. Se isso é pertinente para o cinema e audiovisual como um todo, é ainda mais perceptível no campo do documentário que, já há pelo menos algumas décadas, foca seus olhares no particular, no comum e privado para o cumprimento da promessa de representação do real que caracteriza a tradição do gênero. Contudo, cada vez mais, o documentário contemporâneo tem colocado em cheque essa tradição do representável e, consonante com o paradigma das sensações e a cultura somática, tem investido numa força de expressão sensorial como forma de endereçamento da experiência da realidade e das alteridades.

Intimidade, os afetos e excessos tensionando a tradição do representável

Partindo de dois filmes paradig máticos do edital DOCTV ${ }^{4}$, Claudia Mesquita (2008) faz um breve e pertinente diagnóstico do documentário brasileiro contemporâneo, identificando características que vão além dos filmes analisados. "Particularização do enfoque", "recortes mínimos", "roçando

4. O DOCTV foi um programa de fomento à produção de documentários desenvolvido pelo Ministério da Cultura a partir de 2003 e que teve cinco edições. Os filmes analisados por Mesquita no artigo citado foram Acidente (Cao Guimarães e Pablo Lobato, 2006) e Uma encruzilhada aprazível (Ruy Vasconcelos, 2007). 
singularidades" são algumas das expressões usadas pela autora para definir tal tendência, cujo principal ponto seria o investimento do discurso fílmico na dimensão fragmentária do cotidiano:

\begin{abstract}
Desinvestidos de pretensão prévia de explicação totalizante, informação convencional ou elaboração verbal de significações sobre essas localidades, (...) esses filmes investem na superfície do mundo que se dá à vista e aos ouvidos, recortando informações visuais e sonoras em séries cujos fragmentos - planos muitas vezes estáticos - não montam didaticamente, para o espectador, uma totalidade orgânica, uma imagem de conjunto. O que parece importar é, sobretudo, propor atenção a ambientes banais, incidentes corriqueiros e aparências imediatas que às vezes adquirem, pelo olhar da câmera, inesperado valor estético, lúdico ou afetivo. (Mesquita, 2008, p. 222).
\end{abstract}

A autora pensa essa característica distintiva do documentário brasileiro contemporâneo a partir do que Ismail Xavier (2005) definiu como "uma prosa ordinária do mundo", apontando para o que seria um efeito de "presença pura". Quero chamar atenção aqui, no diálogo com tal diagnóstico feito por Mesquita (2008), que o que se enxerga como presença pura em muitos dos documentários mais aclamados pela crítica acadêmica me parece ser justamente a presença pura de afetos que se performam no cotidiano.

Quero reiterar essa ideia - de afetos que se performam no cotidiano - para apontar que nesses filmes (entre eles o que aqui analiso), o cotidiano não é apenas esfera do privado onde se travam batalhas políticas como se entende o lugar do cotidiano e da esfera privada nas lutas dos movimentos minoritários a partir dos anos 1960, 1970 e 1980 que configurou o que Micheal Renov (2004) chamou de a "nova subjetividade" no campo do documentário. Mais que isso, nesses filmes, o cotidiano é esfera de afetos e de individualidades que mobilizam como afetos e fragmentos os espectadores e o campo do político. Nesse sentido, afasta-se do desejo prioritariamente representativo, para entrar no campo de uma partilha de individualidades e de sensibilidades. 
ano 2 número 4

Dossiê

Vê-se intensificar nesse documentário contemporâneo uma liberação pelo apreço pelas asserções e comprovações totalizantes - um certo "grau de recusa dos vestígios miméticos" (Mesquita, 2008, p. 225) - em nome da exaltação do instante, do valor poético, da expressão da superfície e dos afetos (sejam eles mobilizados em torno de excessos estéticos ou não). Essa não é seguramente "toda" a verdade do documentário recente brasileiro, mas é o diagnóstico de uma parcela dessa produção que é cada vez mais valorizada e singularizada pela crítica acadêmica e pela comunidade de realizadores.

Mesquita (2008) identifica dois paradigmas referenciais no campo do documentário: um que daria conta do impulso mais da ordem do representável (cumprindo, poderíamos dizer, o horizonte de expectativas tradicionalmente associado ao documental) e outro paramétrico "submetendo temas e assuntos a parâmetros formais de abordagem estabelecidos de antemão" a partir dos quais a "realidade se filtra" (idem p. 229). A tendência geral do documentário contemporâneo seria um vínculo maior ao paramétrico e, de modo mais específico, o privilégio a uma mirada mais contemplativa.

Elena e A falta que me faz são, cada um a seu jeito, circulações entre o paramétrico e o representável onde os diálogos com o paradigma das sensações e a cultura do excesso que marca a moral do espetáculo (de modo mais adesista no filme de Petra Costa e de modo mais tensionado no filme de Marília Rocha) posicionam afetos, sensações e emoções.

Assim que o documentário contemporâneo acaba por investir nas experiências individuais e nas singularidades onde, para tanto, parecem fundamentais o que identifiquei como "pactos de intimidade" (Baltar, 2007). A partir dessa tendência é possível e desejável pensar numa certa recusa ao paradigma fundante do domínio do documentário calcado na ideia de evidência e representação do real. A legitimidade do filme de falar do/em nome do real (e assim alinhar-se ao campo do documental) se dará, portanto, não por assertivas totalizantes, mas pelos vínculos afetivos e emotivos organizados em torno das noções de cotidiano, esfera privada, intimidade. 
A ideia de pacto de intimidade se articula como estratégia de autenticidade e legitimação do próprio filme. Trata-se de compor dispositivos dos mais diversos que tem em comum a construção de uma sensação de intimidade e proximidade partilhada entre sujeito do filme - discurso fílmico e espectadores. Este pacto, firmado na tessitura fílmica, substitui a força do argumento como elemento organizativo do discurso no universo do documentário e isto é realizado pelo papel central da figura do personagem e da instância do privado. Entre os dispositivos mais comuns em ação no firmar desse pacto, tenho destacado os distintos diálogos com a imaginação melodramática, a presença do diretor e do aparato fílmico, a força das ações e relatos testemunhais apresentados como conversas e confissões e o uso de estratégias do domínio da ficção, em especial um investimento no uso dos close-ups e planos-detalhe, para justamente reiterar esse efeito emotivo e afetivo de intimidade e interioridade, engendrado especialmente através dos close-ups no rosto.

É importante indicar que nem todos esses elementos estão presentes em $A$ Falta que me faz (apenas o investimento na proximidade da câmera no corpo das personagens em determinados e particulares momentos do filme), mas a maioria deles, principalmente o uso do close no rosto como simbolização da intimidade, pode ser percebida em Elena. Assim, os filmes aqui analisados representam projetos de pactos de intimidade distintos e complexos costurados de modo peculiar através de uma articulação intervalar e tensa entre afetos e excessos.

Afetos e excessos são também estratégias importantes para firmar esses pactos de intimidade, pois mobilizam engajamentos sensoriais e sensacionais. A falta que me faz e Elena organizam modelos diferentes de pactos de intimidade a partir de diálogos particulares (em tensão e graus diversos) entre afetos e excessos.

\section{Afeto e excesso como estratégias e respostas sensíveis}

Antes de entrar propriamente nas notas sobre os filmes, é importante ressaltar que entendo excesso e afeto como efeito e instrumento do contex to contemporâneo e nesse sentido, como respostas estéticas sensíveis à cultura somática e ao paradigma das sensações (centralidade do corpo, espetáculo, sensações). 
Tomo a ideia de afeto como um como um movimento que se tece no âmbito do fílmico em direção à mobilização das sensações do espectador. Tal movimento se dá como uma expressão que se ampara no corpo e para o corpo, contudo, um corpo que ultrapassa o desejo de representação, mas que se sustenta na performance, entendida aqui como a percebe Elena Del Rio (2008), ou seja, como um evento afetivo-expressivo. Diz a autora:

\begin{abstract}
Enquanto a representação é mimética, a performance é criativa e ontogenética. Na representação, a repetição dá luz ao mesmo; na performance, cada repetição encena um único evento. Performance suspende todas as prefigurações e distinções estruturadas, para se tornar o evento no qual novos fluxos de pensamento e sensação podem emergir. (Del Río, 2008, p. 4) ${ }^{5}$
\end{abstract}

Realizando uma ampliação do pensamento de Deleuze sobre afectos e perceptos e sobre um cinema do corpo, Del Rio (2008) procura dar ao afeto um caráter mais flexível intimamente associado à força da expressão da performance do corpo, ou seja, o corpo efetivamente como presença no filme, mas também o filme como corpo no sentido do poder de mobilização (e afetação) do encontro entre corpo-fílmico e corpo de espectador.

Seguindo essa linha de reflexão, termos clássicos na teorização do cinema como espetáculo e prazer visual são repensados na sua correlação com afeto, a partir da dimensão performativa e da força disruptiva em relação à narrativa e à representação. Uma força que se sustenta na capacidade de afetação mobilizada pela expressão do corpo em ação na imagem. “Afetos são, portanto, os poderes do corpo" (Del Rio, 2008, p. 8) .

Para a autora, embora sejam distintos, há entre afeto e emoção uma interconexão fluida: “Afeto precede, dá as condições para, e ultrapassa uma

5. "While representation is mimetic, performance is creative and ontogenetic. In representation, repetition gives birth to the same; in performance, each repetition enacts its own unique event. Performance suspends all prefigurations and structured distinctions, to became the event wherein new flows of thought and sensation can emerge". (DEL RíO, 2008, p. 4)

6. "Affects are thus the powers of the body" (Del Rio, 2008, p. 8) 
particular expressão humana de emoção (...) emoção, no entanto, atualiza e concretiza a maneira como o corpo às vezes é afetado (Del Rio, 2008, p. 10) ${ }^{7}$.

Ao entender afeto e emoção como interconectados, Del Rio consegue ampliar as referências de Deleuze correlacionando às ref lexões que partiram do melodrama como força disruptiva da constrição da narrativa. Momentos de afeto, coerente com o excesso melodramático, que, no interior de narrativa, afeta como sensação e ultrapassa a representação consagrada pela tradição do gênero. Assim, tais momentos de afeto tensionam a própria tradição narrativa, atuando como força desestabilizadora do fluxo da narrativa em si e também das construções morais articuladas na tradição dos gêneros. Tais momentos de afeto se constituem como corpo político que desorganiza os corpos dados na representação do mundo. Podem ser momentos raros e pontuais no filme, mas que tem a força de redirecionar todo nosso olhar para o restante da tessitura narrativa.

Poderíamos pensar, em certo sentido, que certas performances das personagens do documentário instauradas no encontro com a câmera e com os sujeitos ao lado dela mobilizam afetos e reconduzem nosso olhar por todo o filme. Os dispositivos desses filmes contemporâneos tentam de algum modo não recusar essa dimensão performativa desse encontro, ou seja, não reenquadrá-las (ou ao menos tentar não reenquadrá-las totalmente) em esquemas miméticos, desejos representativos e explicativos. Por isso, o elogio ao fragmento, ao instante, aos silêncios e às reticências que marcam os encontros entre sujeitos, câmeras e, correlatamente, espectadores. Tais fragmentos são afetos. Argumento que podemos perceber certas passagens do filme de Marília Rocha nesse sentido, mas isso não se dá apenas em A falta que me faz e muitos outros documentários brasileiros dos últimos anos seguem movimento parecido, como por exemplo, as obras de Cao Guimarães.

Contudo, em muitos documentários recentes, um outro movimento, distinto da mobilização pelo afeto, mas correlato a ele, se processa. O movimento em

7. "Affect precedes, sets the conditions for, and outlasts a particular human expression of emotion(...) emotion nonetheless actualizes and concretizes the way in which a body is sometimes affected by" Del Rio, 2008, p. 10) 
direção ao desejo simbolizador do excesso como estratégia estética. O excesso também se dá no corpo e para o corpo, roçando o universo da performance, no caso predominantemente espetacular, do corpo dado a ver em ação. Tal como o afeto, o excesso se tece no fílmico e mobiliza sensações e sentimentos no corpo do espectador. Mas no caso, tal se dá por força do ato simbolizador mimético, orquestrados reiterada e saturativamente no âmbito da narrativa.

Não quero argumentar aqui por uma dicotomização entre o afeto (lugar da expressão, performance e recusa do mimético-representacional) versus o excesso (reiteração simbólica espetacular e mimética da representação narrativa). Seria enfraquecer ambos os conceitos engessá-los desse modo. Quero marcar uma ideia de que afeto e excesso são elementos intervalares que respondem, cada um a seu modo, ao cenário contemporâneo do paradigma das sensações e da moral do espetáculo. Em alguns casos, excesso e afeto podem chegar a ser sinônimos, em outros, distanciam-se sobremaneira a partir do diálogo que o filme como um todo estabelece com a cultura midiática espetacularizada.

Não é fácil precisar nenhum dos dois elementos (afeto e excesso) na tessitura fílmica e cada autor oferece um caminho que se calca na análise específica de cada obra. Em relação ao excesso, um primeiro caminho tem sido delineá-lo a partir dos gêneros narrativos (seu uso mais contundente, sistemático, mas não exclusivo). Foi desse modo que o termo foi pensando como a marca comum do que Linda Williams (2004) denominou "gêneros do corpo" (tomando de empréstimo e ampliando a expressão de Carol Clover). O excesso seria o denominador comum desses gêneros que convidam a um engajamento sensóriosentimental estabelecido pela narrativa ${ }^{8}$. Ele se dá a partir do corpo em ação como espetáculo e como explosão de êxtase, como atração, em movimentos que performam estados sensoriais e emocionais que, dados a ver audiovisualmente, inspiram no espectador se não os mesmos estados, algo bem próximo.

8. Na minha apropriação das reflexões de Williams, argumento que tal compartilhamento responde a uma necessidade primordial do projeto de modernidade, primordial para a própria construção da ideia de sujeito moderno: as necessidades de personalizar as práticas de consumo em projeções empáticas identificatórias. 
O excesso se apresenta como as específicas articulações da narrativa numa reiteração constante, como se cada elemento da encenação - desde a música, a atuação, os textos, a visualidade, as performances - estivessem direcionados para uma mesma função; ou seja, como se todas as instâncias dissessem o mesmo, a serviço de uma obviedade ${ }^{9}$ estratégica que toma corpo de maneira exuberante e espetacular, e assim mobiliza as projeções e engajamentos empáticos e passionais.

Para catalisar esse convite ao engajamento, o apelo ao visual (ao narrar a partir de imagens que se estruturam como símbolos que são exacerbadamente repetidos ao longo do filme) é elemento fundamental, conduzindo ao que Peter Brooks (1995) chama de "superdramatização" da realidade através de uma estética do astonishment (que eu gostaria de poder traduzir por ar rebatamento).

No meu entendimento, o excesso reitera e satura, promove um fluxo de imagens e sons que a um só tempo esclarece e afoga, intensifica a força espetacular dos símbolos exacerbadamente elencados na tessitura fílmica e adensa a força disruptiva e excitante do êxtase (como vetor da ação e como convite à semelhante reação do espectador) do corpo fora de si (beside itself). Procedimentos imagéticos (a câmera colada ao corpo, por exemplo) e sonoros (mobilizando a sensorialidade através dos ruídos), promovem um uso de elementos audiovisuais para além da função de narração (storytelling), propondo um super-envolvimento em sensações e emoções.

No seu uso mais comum nas tradições dos gêneros do corpo, o excesso conduz a vínculos empáticos configurados muito frequentemente, mas não exclusivamente, em temáticas que envolvem instâncias moralizantes que serão articuladas de maneira exacerbada e caracterizadas pelo predomínio da visibilidade (reiterando imagens de fácil apreensão) que são costuradas no tecido fílmico como simbolizações exacerbadas.

9. A noção de obviedade não deve ser entendida aqui como um elemento pejorativo, mas como um regime de expressividade que marca a economia reiterativa do excesso e com ela a "facilitação", diria imediatez, do engajamento entre obra e público. Engajar-se na narrativa pressupõe colocar-se em estado de "suspensão", ou seja, sentimental e sensorialmente vinculado a ela. 
ano 2 número 4

Dossiê

\title{
A falta que me faz e Elena - pathos entre excesso e afeto
}

A sinopse de A falta que me faz diz:

\begin{abstract}
Durante um inverno, rodeadas pela Serra do Espinhaço, um grupo de meninas vive o fim da juventude. Um romantismo impossível deixa marcas em seus corpos e na paisagem a seu redor. Em meio a conversas, obrigações e prazeres cotidianos, cada uma delas encontra uma maneira particular de contornar a solidão e enfrentar as incertezas de um futuro próximo.
\end{abstract}

Marcado já no discurso de distribuição oficial do filme está, portanto, o desejo de chamar atenção para as marcas no corpo dos afetos e sentimentos. Tais marcas são reiteradas e simbolizadas ao longo do filme em close-ups nos pedaços de corpos das personagens singularizando de maneira hapticamente intensa o ato de marcar-se corporalmente.

As sequências iniciais já atestam esse desejo, marcando nossa primeira entrada no filme através de uma câmera-corpo colada ao corpo das personagens. São fotografias que enquadram os corpos sem rosto, ressaltando nos primeiros 
planos especialmente os peitos e o colo com suas marcas de individuação: um colar, um coração e logo depois, as marcas feitas na pele. Tais fotos são projetadas na tela ao som de uma canção do repertório popular associado ao brega cantado a capela por uma das personagens.

As cenas seguintes contrastam significativamente com essas fotografias iniciais pela estrutura do plano - longos planos gerais de paisagens do horizonte de montanhas que marca a região próxima a Curralinho, cidade de Minas Gerais onde se ambienta o filme. Nota-se particularmente a quase ausência de pessoas nessas paisagens. Corte seco e somos jogados em meio a um salão onde casais dançam. A câmera vai se movimentando por entre os corpos, dançando com eles, muito próxima, muito móvel, formando quadros de pedaços de encontros de corpos.

Nossa entrada no filme é, portanto, entre fragmentos de corpos e de paisagens sem, no entanto, identificar precisamente nenhuma delas, mas, contudo, singularizando as ações nos corpos (sobretudo os fragmentos de corpos na primeira sequência de fotos). Ao longo do documentário, teremos ainda alguns outros inserts de sequências como essas, onde o fluxo da narrativa parece parar para a contemplação desses pedaços de performance, de corpos e de detalhes nas paisagens que, em conjunto, organizam símbolos (entre o afeto e o excesso) do que as falas deixam entreouvir mobilizando assim afetos.

Argumento que tais inserts respondem a um diálogo entre o excesso e o afeto operado pelo filme de Marília Rocha. Não exatamente uma adesão às narrativas genéricas marcadas pelo excesso (como veremos no filme de Petra Costa), mas um diálogo tenso que se estabelece a partir de inserts, fragmentos estrategicamente entremeados pelo discurso fílmico que é de modo geral marcado pela contenção.

Esses inserts de afeto-excesso são precisamente a sequência inicial e os outros momentos do filme (não muitos, mas significativos, por isso chamo de inserts), onde a câmera se mostra hapticamente próxima ao corpo das personagens marcando um comportamento distinto da sua atitude geral ao longo do filme, reafirmando características comuns a certo cinema 
ano 2 número 4

Dossiê

contemporâneo intensamente afetivo em atitudes que remetem ao que Laura Marks (2000) identificou como uma visualidade háptica e ao que Erly Vieira Jr.(2012) propõe como uma "câmera-corpo".

A primeira cena de fala do filme se dá nos moldes de um documentário observacional onde vemos Priscila marcando com uma agulha sua perna. A câmera se aproxima singularizando o ato que é também singularizado pelos comentários das amigas ouvidos em off do antecampo: "Priscila, essa marca vai ficar de vera", "Vem cá procê ver o que que ela faz", "Você é doida Priscila".

Na continuação dessa cena, as a migas conversam sobre a ação, aparentemente comum a todas, de marcar, a caneta e agulha, o corpo em especial com nomes de suas paixões. "Se retocar vai ficando?", pergunta a diretora. "Mas eu não retoco não, dói demais", responde Priscila. Muitos segundos de silêncio, troca de olhares entre personagem e câmera. Nada mais precisa ser explicado, só a presença e o gesto ficam. Mais para a metade do filme, veremos sequências de closes de letras e corações fincados nas árvores, montados em corte seco e cobertos apenas com os ruídos da paisagem. Um tratamento estético tão análogo às imagens iniciais que não há como não estabelecer uma conexão entre esses gestos de marcar/inscrever/singularizar/expressar encontros.

A falta que me faz é composto de pedaços de conversas e ações que não se interligam numa tradicional continuidade retórica (como diria Nichols) de modo a estruturar e oferecer uma linha de explicação e/ou argumentação da realidade. São fragmentos do cotidiano - de modo geral expressos por uma câmera distanciada, observacional e por uma faixa sonora de ruídos e conversas - que deixam a forte sensação de que tal cotidiano é atravessado pelas relações amorosas e de afetos e desafetos entre os personagens. É notável a quase ausência da fala do masculino (os homens são falados, mas praticamente não falam) e o fato de que as paixões e amores cotidianos não são expressos como roteiro de novela (com grandes frases de efeito, peremptórias e exuberantes de amor e felicidade). Não; elas têm um quê de tédio, de banalidade.

Esse efeito (um quê de tédio de paixões) é ancorado pelo comportamento geral distanciado da câmera, pelo caráter fragmentário das cenas e pelos 
silêncios partilhados entre as falas, em especial entre as interações com a câmera e a diretora. "silêncio cheio de sons (...) vazio pleno de coisas", como diz Denilson Lopes (2012, p. 117)

De modo geral, a câmera e a presença do aparato documental (em especial a voz da diretora conduzindo conversas a partir do extraquadro) são mantidas à distância das personagens, cuja interação com a diretora e filme se dá a partir de silêncios, frases entrecortadas e muitos momentos de quase timidez ou constrangimento no performar-se. As personagens são convocadas a responder sobre suas vidas e ações cotidianas - relações de amizade, de família e mais especialmente suas paixões e relações amorosas - mas o fazem com certo constrangimento no performar-se que o filme deixa aparecer.

Um bom exemplo se dá por volta de 13'24". Valdênia está se balançando na cadeira quando ouvimos a diretora perguntar: "Valdênia, fala a verdade, você acha que alguém se mata por amor?". A resposta é um pequeno riso, "ah, não sei não.., ah deve matar né?...". Em meias respostas e muitas reticências, a história de Priscila e sua irmã (que já tentaram se matar por amor) é contada por Valdênia (sem muita clareza, sem nenhuma linearidade e fluência de depoimento/entrevista). A câmera fica quase imóvel (um leve zoom, mas que não chega a fazer um close-up), a diretora quase em silêncio e nós ouvindo os fragmentos do relato. Nada de excesso se apresenta aqui.

Assim, se nas conversas ao longo do filme a sensação que transparece é de distância e secura diante do corriqueiro, em certas cenas, muito marcadas, tais como nas sequências iniciais, a proximidade excessiva da câmera nos corpos dos personagens diminui tal impressão.

Elena, por outro lado, estabelece uma adesão maior, em especial a imaginação melodramática. O filme é uma narrativa pessoal que se centra na relação da diretora com a memória de sua irmã Elena. Atriz e dançarina, Elena parte para Nova York e lá se mata. Irmã e mãe atravessam o filme em busca da memória de Elena, sustentada nas muitas imagens e sons de arquivo familiar, e do que parece ser uma superação de um destino comum. “Elena viaja para Nova York com o mesmo sonho da mãe: ser atriz de cinema. Deixa para trás uma infância 
ano 2 número 4

Dossiê

passada na clandestinidade dos anos de ditadura militar e deixa Petra, a irmã de 7 anos. Duas décadas mais tarde, Petra também se torna atriz e embarca para Nova York em busca de Elena.", diz a sinopse oficial do documentário.

A montagem do filme deixa claro que Elena, Petra e a mãe compartilharam mais do que uma mesma dor, mas traços e destinos quase comuns. A relação de paridade entre Elena e Petra e reitera constantemente no texto em primeira pessoa que narra o filme, em quadros repetidos ao longo do filme que compõem um close do rosto dessas três mulheres, enquadrados de um mesmo ângulo e, em algumas passagens, com o mesmo movimento de câmera. Refiro-me aqui às várias sequências ao longo do filme em que Petra ou sua mãe caminham pelas ruas de Nova York, revivendo/re-performando os dias em que ali viveram e que antecederam o suicídio de Elena. Nessas cenas, a câmera extremamente aproximada no perfil do rosto das personagens as acompanha no seu caminhar; no quadro, as ruas não existem, apenas o rosto em movimento ocupa a tela e nós estamos como que colocados lado a lado. Enquanto andam, rememoram e toda a cena nos causa um impacto de conversa íntima. Quero chamar atenção para o efeito da repetição desse quadro, colocando o rosto das três como um símbolo em si, retomado constante e excessivamente ao longo da narrativa.

Um outro rosto também é fortemente elencado como símbolo da dor e destino compartilhados pelas três (mãe e irmãs): refiro-me ao rosto desenhado em pastel pela mãe. Este desenho, enquadrado em primeiro plano enquanto está sendo produzido (vemos/sentimos as mãos passeando pelo papel), aparece duas vezes no filme e é mencionado pela mãe ao lembrar que quando ela teve uma primeira crise de depressão desenhava este rosto.

A primeira aparição dessa cena se dá aproximadamente aos sete minutos. Nessa passagem, a voz de Petra reconta a história da mãe, cobrindo imagens de arquivo em preto e branco de um filme não montado onde a mãe aparece. As imagens do material de arquivo estão em um leve slowmotion, a trilha sonora melodiosa que atravessa momentos chaves do documentário estabelece a continuidade das cenas contemporâneas para o arquivo e no meio dessa narração aparece, também em preto e branco e em slowmotion, o retrato em pastel sendo desenhado por uma mão levemente enrugada: “um dia, sentada 
em frente a penteadeira do seu quarto ela faz um desenho, o desenho da sua tristeza", diz Petra nesse momento.

Mais próximo ao final do filme, reencontramos o close no rosto da mãe, olhos fechados, flutuando na água ela relembra quando começou a "querer morrer", conforme suas palavras: "e na primeira crise que eu lembro de ter, no quarto assim, eu fiquei desenhando, em frente ao espelho, meu rosto com lápis azul marinho, roxo, preto". Neste momento, a mesma imagem da mão que desenha parece, agora colorida, não mais o arquivo, mas a presentificação visual (coerente com o modo de excesso) da memória e do destino compartilhado entre mãe e filhas. A mãe segue narrando que, na véspera da morte, Elena achou um pôster de uma peça que lembrava muito este desenho: "E ela pregou na parede do quarto nessa noite em que ela fez essa encenação da morte", diz. A sequência se encerra numa passagem do close do rosto da mãe de olhos fechados, para o close de suas mãos desenhando esse rosto, "desenho de sua tristeza".

É interessante notar, para os argumentos que estou traçando aqui sobre a adesão estratégica do filme ao excesso e à imaginação melodramática, que a sequência descrita acima é antecipada por outra bastante significativa do argumento de um destino e dor compartilhados. Trilha musical reaparece, imagens de um espelho quebrado boiando na água refletem o rosto de Petra; sua voz off diz (reiterando na chave da obviedade a imagem): "Me olho no espelho e não vejo nada atrás dos meus olhos". A música estabelece a continuidade para a cena, já mencionada, da mãe, também em close do seu rosto, flutuando.

Essa ideia de destino comum compartilhado - ainda que com desenlaces diferentes - fica obviamente colocada desde as primeiras sequências do filme quando Petra refaz os caminhos de Elena, andando nas ruas de Nova York, repetindo gestos da irmã que reconheceremos ao longo do filme através dos usos das muitas imagens de arquivo familiar com vídeos de Elena na adolescência e nos primeiros anos de carreira.

O documentário é atravessado por inserções de elementos formais que dão corpo às lembranças, à dor, às sensações. Escreveu o crítico Carlos Alberto Mattos em seu blog ...rastros de carmattos (10 de maio de 2013): 
ano 2 número 4

Dossiê

\begin{abstract}
Não há no filme nem a objetividade dos relatos documentais nem a subjetividade puramente confessional dos filmes em primeira pessoa. Elena busca uma terceira via, que é a transformação do fato em memória e desta em reinvenção formal. (...) Elena corre o risco de parecer bonito demais, ainda que essa beleza seja a própria matéria de que é feito o seu dolorido encantamento.
\end{abstract}

Concordo com sua análise e acrescento que tal formalismo, em sua função de transformar a memória pessoal em sensação compartilhada, se dá na apropriação do excesso como elemento estético preponderante.

Argumento que o uso reiterado do slowmotion, em especial das cenas do close nos rostos, as reencenações das performances e movimentações corporais de Elena feitas por Petra e as encenações de imagens de corpos de mulheres em vestidos de tecido fino e translúcidos flutuando em águas turvas são presenças do excesso na tessitura fílmica que tem como função instaurar símbolos que presentificam o compartilhamento do destino, da dor e da memória das três personagens (Elena, Petra e a mãe). Que tais imagens aparecem repetidamente ao longo do filme é ainda mais cabal na adesão ao excesso como âncora do diálogo com a imaginação melodramática.

As incorporações da imaginação melodramática conseguem garantir o impacto e sucesso do filme (que arrebatou prêmios de Júri Popular e de crítica) ${ }^{10}$ e não raro as reações do público explicitam sensações de comoção diante da dor e memória compartilhada.

\title{
Notas Finais
}

Em síntese, quero argumentar com esses comentários analíticos a partir de A falta que me faz e Elena, que, a partir do elogio à "maquinação", a exposição da construção do dispositivo documentário, às encenações e aos fragmentos como formas do narrar documental, estamos diante de duas vertentes distintas

10. Entre os prêmios estão: melhor direção, melhor montagem, melhor direção de arte e melhor filme pelo júri popular no $45^{\circ}$ Festival de Brasília do Cinema Brasileiro, melhor documentário no Films de Femmes 2013 e no $6^{\circ}$ Los Angeles Brazilian Film Festival. 
de diálogo com o contexto contemporâneo da hiperindividuação, da moral do espetáculo que marca a cultura somática e ao paradigma das sensações. Respostas sensíveis a esse cenário que se dão no intervalo entre o excesso e a mobilização de afetos e em outros casos, na coagulação entre ambos.

Formas que vão além de uma mera adesão ao universo do excesso como modelo estético ou como sensibilidade geral da cultura midiática espetacularizada, mas que tomam tal sensibilidade (ou talvez melhor dizendo, tal imaginação) como esfera de tensão para compor o tecido fílmico.

Percebo tal tensão mais forte em A falta que me faz, pois o filme incorpora a imaginação de excesso que atravessa as personagens (marcar-se com símbolos de paixão na pele, a dança, o repertório cultural do cancioneiro brega, as explosões de paixões em atos hiperdramáticos) sem aderir a ela. Incorpora a presença do excesso no cotidiano das personagens - e o faz através dos inserts analisados aqui que mobilizam afetos-performativos - mas não o abraça, fincando-se no limite da contenção e é desde tal limite que ele mobiliza afetos.

Já Elena abraça o excesso e a imaginação melodramática como forma de construção da lembrança a ser compartilhada com os espectadores, e através dela o reencontro com a memória da irmã morta e com a presença corporal da mãe como personagem. A adesão ao excesso em Elena organiza uma relação de projeções espetacularizadas (em maior ou menor grau) articuladas em um impulso exacerbadamente simbolizador que toma corpo de modo mais forte na forma milimétrica com que o mesmo quadro do close nos rostos da irmã morta, da diretora e da mãe são apresentados e reiterados ao longo do filme. Tais simbolizações exacerbadas (além de outras como o uso da água e das ruas; a sequência dos corpos de mulheres flutuando no lago que abre e fecha o filme como uma espécie de videoclipe, ou mesmo a repetição por parte de Petra dos gestos, movimentos de corpo e performances da irmã ao longo do filme) articulam empatias e comoções diante dessa narrativa tão privada que se apresenta ao olhar público no documentário.

A falta que me faz e Elena se movem no intervalo entre afeto e excesso ao propor pactos de intimidade distintos, mas que nos colocam questões sobre a centralidade do cotidiano como expressão do sensível e da alteridade. 


\section{Referências}

ano 2 número 4

Dossiê

BALTAR, Mariana. Realidade lacrimosa: diálogos entre o universo do documentário e a imaginação melodramática. 2007. Orientador: João Luiz Vieira. Tese (Doutorado) - Universidade Federal Fluminense, Curso de Pós-Graduação em Comunicação.

. "Cotidianos em performance. Estamira encontra as mulheres de Jogo de Cena" In. Migliorin, Cezar. (org). Ensaios no real. O documentário brasileiro hoje. Rio de Janeiro: Azougue, 2010.

. "Tessituras do excesso: notas iniciais sobre o conceito e suas implicações tomando por base um procedimento operacional padrão". Revista Significação, ano 39, n³8, 2012.

BROOKS, Peter. The Melodramatic Imagination Balzac, Henry James, melodrama and the mode of excess. Yale University Press, 1995. [Primeira edição: 1976].

CLOUGH, Patricia. The affective turn: Theorizing the social. Durham: Duke University Press, 2007.

COMOLLI, Jean-Louis. Ver e poder. A inocência perdida: cinema, televisão, ficção e documentário. Belo Horizonte: Editora UFMG/Humanitas, 2008.

DEL RíO, Elena. "Introduction. Cinema and the Affective-performative". In Deleuze and the cinemas of performance. Edinburg: Edinburg University Press, 2008.

ECO, Umberto. A Vertigem das Listas. Rio de Janeiro: Record, 2010.

ENNE, Ana Lúcia. "O sensacionalismo como processo cultural”. In. Comunicação e Melodrama. EcoPós, publicação da Pós-Graduação em Comunicação e Cultura, v. 10, n. 2, julho-dezembro de 2007.

LOPES, Denilson. No coração do mundo. Rio de janeiro: Rocco, 2012.

LINS, Consuelo e MESQUITA, Claudia. Filmar o real - sobre o documentário brasileiro contemporâneo. Rio de Janeiro: Zahar, 2008

FREIRE COSTA, Jurandir. O vestígio e a aura. Corpo e consumismo na moral do espetáculo. Rio de Janeiro: Garamond, 2004. 
MARKS, Laura. The Skin of Film. Durham: Duke University Press, 2000.

MESQUITA, Claudia. "A superfície do cotidiano: uma aproximação a Acidente e Uma encruzilhada aprazível”. In. LEAL, B., GUIMARÃES, C. e MENDONÇA, C. (orgs). Entre o sensível e o comunicacional. Belo Horizonte: Autêntica, 2010.

RENOV, Michael. "The Subject of Documentary". Collection Visible Evidence Vol. 16. Minneapolis: Univ. of Minnesota Press, 2004.

VIEIRA Jr, Erly. Marcas de um realismo sensório no cinema contemporâneo. 2012. Tese de Doutorado (Orientador: Denilson Lopes). ECO - Programa de Pós-graduação em Comunicação da UFRJ.

WILLIAMS, Linda. "Film Bodies: gender, genre and excess". In: BAUDRY, L. e COHEN, M.(org). Film Theory and criticism. Oxford: Oxford Universty Press, 2004.

TÜRCKE, Christoph. Sociedade Excitada - filosofia da sensação. Campinas/SP: Editora da Unicamp, 2010.

XAVIER, Ismail. O discurso cinematográfico: a opacidade e a transparência. 3.ed. São Paulo: Paz e Terra, 2005.

\section{Sites acessados}

http://www.revistacinetica.com.br/faltaquemefaz.htm (acessado em 3 de maio de 2013) http://www.mariliarocha.com/trabalhos/falta (acessado 3 de maio de 2013) http://www.elenafilme.com/ (acessado em 26 de setembro de 2013) http://carmattos.com/2013/05/10/ela-elas-elena/ (acessado em 26 de setembro de 2013) 


\section{Ficha Técnica dos Filmes Analisados}

ano 2 número 4

Dossiê

Título: A Falta que me faz

Duração: 85 min

Lançamento (Brasil): 2009

Direção: Marília Rocha

Personagens: Alessandra Ribeiro, Priscila Rodrigues, Shirlene Rodrigues, Valdênia Ribeiro, Paloma Campos

Diretora Assistente: Clarissa Campolina

Produção: Luana Melgaço

Produtor Associado: Helvécio Marins Jr., Felipe Duarte

Fotografia: Alexandre Baxter, Ivo Lopes Araújo

Montagem: Francisco Moreira, Marília Rocha

Desenho de som: O Grivo

Trilha sonora: Arthur H.

Design Gráfico: Marilá Dardot

Coordenação de Distribuição: Felipe Duarte

Distribuição: Cia do Filme, Teia I Lume Filmes (DVD)

- Lançado em salas de cinema em 2010, em DVD Home Video em 2011, exibição em TV, pelo Canal Brasil, em 2011. 
Título: Elena

Duração: 82 minutos

Lançamento (Brasil): 2012

Direção: Petra Costa

Elenco: Elena Andrade, Li An e Petra Costa

Produção: Busca Vida Filmes

Produtor Associado: Felpe Duarte e Sara Dosa

Fotografia: Janice D’Avila, Will Etchebehere e Miguel Vassay

Montagem: Marília Moraes e Tina Baz

Desenho de som: Olivier Goinard e Guile Martins

Trilha sonora original: Vitor Araújo, Fil Pinheiro, Maggie Hastings Clifford e Gustavo Ruiz 